\title{
Asas-Asas dan Landasan Teoretis dalam Naskah Akademik Rencana Pembangunan Jangka Menengah Daerah Kabupaten Tulang Bawang Tahun 2011-2016
}

\author{
Muhtadi
}

Dosen Bagian Hukum Tata Negara FH Universitas Lampung

\begin{abstract}
Abstrak
Menggunakan pendekatan normatif tulisan ini bertujuan untuk menjabarkan asasasas dan landasan teoretis dalam pembentukan Naskah Akademik Rencana Pembangunan Jangka Menengah Daerah (RPJMD) Kabupaten Tulang Bawang Tahun 2011-2016. Hasil penelusuran kepustakaan ditemukan bahwa asas-asas dalam penyusunan RPJMD meliputi asas hukum yang diatur dalam Undangundang Pemerintahan Daerah dan Undang-undang Pembentukan Peraturan Perundang-undangan. Adapun landasan teoretisnya mencakup antara lain wewenang pemerintahan daerah dalam menjalankan asas otonomi seluas-luasnya berdasarkan Undang-Undang Dasar Tahun 1945.
\end{abstract}

Kata kunci : RPJMD, asas-asas, landasan teoretis dan Naskah Akademik.

\section{Latar Belakang}

Peraturan daerah (perda) merupakan instrumen hukum dalam melaksanakan urusan wajib dan urusan pilihan yang menjadi kewenangan pemerintahan daerah. Dalam hirarki peraturan perundangundangan, perda adalah norma hukum yang bersifat pengaturan di daerah yang pembahasannya menjadi kompetensi Dewan Perwakilan Daerah Rakyat (DPRD) bersama Kepala Daerah.

Pasal 18 ayat (5) UndangUndang Dasar Tahun 1945 (UUD Tahun 1945) memberikan kewenangan seluas-luasnya kepada daerah otonom untuk mengurus urusannya sepanjang tidak ditentukan sebagai urusan pemerintah (pusat), yang kemudian diatur lebih lanjut dalam Pasal 10 sampai Pasal 14 Undang-Undang Nomor 32 Tahun 2004 tentang
Pemerintahan Daerah (UU Pemda), ${ }^{1}$ sebagaimana diubah terakhir dengan Undang-Undang Nomor 12 Tahun 2008 tentang Perubahan Kedua Atas Undang-Undang Nomor 32 Tahun 2004 tentang Pemerintahan Daerah ${ }^{2}$, kemudian dijabarkan lebih lanjut dengan Peraturan Pemerintah Nomor 38 Tahun 2007 tentang Pembagian Urusan Pemerintahan Antara Pemerintah, Pemerintahan Daerah Provinsi, dan Pemerintahan Daerah Kabupaten atau Kota. ${ }^{3}$ Demikian pula yang dikehendaki sebagai substansi yang perda sebagaimana ditentukan dikehendaki UndangUndang Nomor 12 Tahun 2011 tentang Pembentukan Peraturan

\footnotetext{
1 Lembaran Negara Republik Indonesia (LNRI) Tahun 2004 No. 125, Tambahan Lembaran Negara Republik Indonesia (TLNRI) No. 4437.

${ }^{2}$ LNRI Tahun 2008 No. 59, LNRI No.4844.

${ }^{3}$ LNRI Tahun 2008 No. 83, TLNRI No.4787.
} 
Perundang-undangan (UU P3), ${ }^{4}$ lebih dari itu, Pasal 14 UU P3 menyebutkan bahwa Materi muatan Peraturan Daerah Kabupaten berisi materi muatan dalam rangka penyelenggaraan otonomi daerah dan tugas pembantuan serta menampung kondisi khusus daerah dan/atau penjabaran lebih lanjut Peraturan Perundang-undangan yang lebih tinggi. Dengan demikian, urusan pemerintahan daerah dalam skala Kabupaten Tulang Bawang Barat baik urusan wajib ataupun urusan pilihan yang terkait dengan pemenuhan hak-hak dasar ataupun karena kekhasan daerah secara normative diatur dengan peraturan daerah.

Pasal 14 ayat (1) huruf a UU Pemda menyebutkan bahwa salah satu urusan wajib yang menjadi kewenangan pemerintah daerah kabupaten yang dilaksanakan dalam skala kabupaten adalah perencanaan dan pengendalian pembangunan, yang secara sistematis dalam Pasal 154 UU tersebut menegaskan bahwa tahapan, tata cara penyusunan, pengendalian, dan evaluasi pelaksanaan rencana pembangunan daerah diatur lebih lanjut dengan Peraturan Pemerintah yang berpedoman pada perundangundangan. Tindak lanjut ketentuan tersebut selanjutnya disahkan Peraturan Pemerintah (PP) Nomor 8 Tahun 2008 tentang Tahapan, Tata cara Penyusunan, Pengendalian, dan Evaluasi Pelaksanaan Rencana Pembangunan Daerah. ${ }^{5}$ Ketentuan

4 LNRI Tahun 2011 No. 82, TLNRI No. 5234.

${ }^{5}$ LNRI Tahun 2008 No. 21, TLNRI No. 4817.
Pasal 20 ayat (3), ${ }^{6}$ Pasal $37,,^{7}$ Pasal 42 ayat $(2)^{8}$ dan Pasal $51^{9}$ PP tersebut menegaskan untuk pembuatan pedoman kegiatan yang terkait dengan pelaksanaan Musyawarah Rencana Pembangunan (Musrenbang), Pedoman penyusunan perencanaan dan penganggaran terpadu, dan Pedoman pengendalian dan evaluasi rencana pembangunan daerah diatur lebih lanjut dengan Peraturan Menteri. Atas pendelegasian kewenangan tersebut, Menteri Dalam Negeri menerbitkan Peraturan Menteri Dalam Negeri (Permendagri) Nomor 54 Tahun 2010 tentang Pelaksanaan Peraturan Pemerintah Nomor 8 Tahun 2008 tentang Tahapan, Tata cara Penyusunan, Pengendalian, dan Evaluasi pelaksanaan Rencana Pembangunan Daerah menyebutkan bahwa Rencana Pembangunan Jangka Menengah Daerah (RPJMD).

Secara spesifik Pasal 75 ayat (1) Permendagri memerintahkan pembuatan peraturan daerah tentang Rencana Pembangunan Jangka Menengah Daerah (RPJMD) harus sudah menyerahkan Raperda RPJMD paling lambat 5 (lima) bulan setelah pelantikan Bupati. Senada dengan itu, Pasal 27 ayat (2) UndangUndang Nomor 25 Tahun 2004 tentang Sistem Perencanaan

\footnotetext{
${ }^{6}$ Ketentuan lebih lanjut mengenai tata cara pelaksanaan Musrenbang diatur dengan Peraturan Menteri.

7 Pedoman penyusunan perencanaan dan penganggaran terpadu sebagaimana dimaksud dalam Pasal 36 ayat (1) huruf a diatur lebih lanjut dengan Peraturan Menteri.

${ }^{8}$ Tata cara koordinasi antarprovinsi di dalam penyusunan rencana pembangunan daerah diatur lebih lanjut oleh Menteri.

9 Pedoman pengendalian dan evaluasi rencana pembangunan daerah diatur lebih lanjut dengan Peraturan Menteri.
} 
Pembangunan
menyebutkan bahwa tata cara penyusunan RPJP Daerah, RPJM Daerah, Renstra-SKPD, RKPD, Renja-SKPD dan pelaksanaan Musrenbang Daerah diatur dengan Peraturan Daerah.

RPJM secara normative oleh Pasal 1 angka 11 Undang-Undang Nomor 25 Tahun 2004 diuraikan sebagai dokumen perencanaan untuk periode 5 (lima) tahun, pengertian serupa terdapat dalam Pasal 1 angka 5 PP Nomor 8 Tahun 2008, demikian pula makna yang terdapat dalam Pasal 1 angka 10 Permendagri yang secara spesifik menyematkan anak kalimat daerah di belakang RPJM.

Pembangunan Daerah menurut Pasal 1 angka 7 Permendagri adalah pemanfaatan sumber daya yang dimiliki untuk peningkatan kesejahteraan masyarakat yang nyata, baik dalam aspek pendapatan, kesempatan kerja, lapangan berusaha, akses terhadap pengambilan kebijakan, berdaya saing, maupun peningkatan indeks pembangunan manusia. Sedangkan Pasal 1 angka 8 Permendagri menyebutkan bahwa Perencanaan pembangunan daerah adalah suatu proses penyusunan tahapan-tahapan kegiatan yang melibatkan berbagai unsur pemangku kepentingan di dalamnya, guna pemanfaatan dan pengalokasian sumber daya yang ada, dalam rangka meningkatkan kesejahteraan sosial dalam suatu lingkungan wilayah/ daerah dalam jangka waktu tertentu.

Sebagai salah satu dari tiga daerah otonom baru di Provinsi Lampung, dibentuk dengan UndangUndang Nomor 50 Tahun 2008

${ }^{10}$ LNRI Tahun 2004 No. 104, TLNRI No. 4421. tentang Pembentukan Kabupaten Tulang Bawang Barat Di Provinsi Lampung, ${ }^{11}$ Kabupaten Tulang Bawang Barat dalam rencana pengembangan jalur tranportasi nasional berada dalam jaringan lintas timur sumatera, transportasi bebas hambatan, dan kereta api nasional. Sedangkan ketersediaan sumber daya alam untuk pengembangan produk pertanian berbasis keunggulan dan kekhasan local dapat menjadi unggulan dan dapat berkompetisi secara nasional, disamping itu melimpahnya sumber daya alam didukung dengan dominasi sumber daya manusia yang berada dalam masa produktif berdasarkan data BPS 2010 mencapai $74,32 \%$ atau 198.235 jiwa, yang kemudian didukung dengan tingginya komitmen aparatur penyelenggaran Negara untuk meningkatan dan bahkan percepatan pembangunan merupakan factorfaktor pendukung dan modal pembangunan Kabupaten Tulang Bawang masa depan, namun demikian, tingginya jumlah penduduk miskin yang berdasarkan catatan BPS terdapat $24.515 \mathrm{KK}$ atau sekitar $35,71 \%$ dari total 266.703 jiwa, infrastruktur yang rusak di sebagian besar kecamatan, sarana telekomunikasi yang rendah, luasnya lahan kritis atau tidak produktif yang mencapai $15 \%-17,5 \%$ terjadinya perubahan fungsi lahan dari lahan produktif menjadi perumahan, keamanan yang kurang kondusif merupakan factor-faktor internal yang dapat mempengatuhi dan berpotensi menggagalkan atau setidak-tidaknya membuat mandeg pembangunan. Disamping itu, terdapat factor eksternal yang antara

\footnotetext{
11 LNRI Tahun 2008 No. 187, TLNRI N omor 4934.
} 
lain nilai tukar rupiah yang rendah, inflasi yang tinggi yang secara nasional juga terjadi berdampak pada rendahnya daya beli masyarakat yang pada akhirnya berakibat rendahnya produktifitas masyarakat Tulang Bawang, demikian pula kondisi alam yang kurang memberi dukungan optimal pada pengembangan potensi pertanian dapat berdampak langsung pada tingat produksi pertanian yang merupakan sumber utama pendapatan masyarakat.

Factor-faktor sebagaimana tersebut dapat menjadi penghambat kemajuan Tulang Bawang Barat jika salah dalam pengelolaannya, atau salah mengurus (mismanagement) pemerintahan daerah, namun demikian dalam kontek manajerial yang visioner, futuristik yang sedapat mungkin menerapakan prinsipprinsip good and clean government factor-faktor tersebut justeru menjadi modal dan tantangan mencapai tujuan pembangunan untuk melindungi segenap bangsa Indonesia dan seluruh tumpah darah Indonesia dan untuk memajukan kesejahteraan umum, mencerdaskan kehidupan bangsa, dan ikut melaksanakan ketertiban dunia. Secara normative, implementasi manajerial tersebut diimplementasikan dengan adanya instrument hokum yang memberikan kepastian hokum, keadilan dan kemanfaatan dalam pelaksanaan pembangunan yang dituangkan dalam bentuk produk hokum daerah yang menjamin bahwa pelaksanaan pembangunan direncanakan, dilaksanakan dan dievaluasi secara sistematis, terukur dan dapat dipertanggungjawabkan berdasarkan peraturan perundang-undangan.

Berdasarkan hal tersebut, apa yang menjadi asas-asas dan landasan teoretis dalam pembentukan RPJMD Kabupaten Tulang Bawang Barat Tahun 2011-2106?

\section{Pembahasan}

\subsection{Asas-asas dalam Naskah Akademik RPJMD}

Asas (Beginzel atau principe: Bahasa Belanda atau principle Bahasa Inggris) dalam Kamus Besar Bahasa Indonesia (KBBI) didefinisikan sebagai (1) dasar hokum, (2) dasar; dan (3) cita-cita. ${ }^{12}$ Adapun prinsip dalam kamus Bahasa Indonesia kontemporer diartikan sebagai dasar yang berupa kebenaran yang menjadi pokok berpikir atau bertindak, ${ }^{13}$ yang istileh tersebut merupakan adalah adaptasi istilah asing principle (Bahasa Inggris) dan oleh Hornby sebagaimana dikutip Rusli Effendi dkk didefinisikan sebagai basic truth atau general law of cause and effect. ${ }^{14}$ Black's Law Dictionary mengartikan principle sebagai a fundamental truth or doctrinal, as of law: a comprehensive rule of doctrine whinch furnishes a bsic or origin for other; a settled rule of action, procedure, or determination. ${ }^{15}$

Asas atau prinsip apabil dikaitkan dengan hokum, maka asas hokum menurut Scholten adalah

\footnotetext{
12 Tim Penyusun, Kamus Besar Bahasa Indonesia, (Jakarta: Departemen Pendidikan dan Kebudayaan RI, 2002), hlm. 52.

13 Peter Salim dan Yenny Salim, Kamus Bahasa Indonesia Kontemporer, (Jakarta: Modern English Press, 1991), hlm. 97.

${ }^{14}$ Rulis Effendi, dkk, Teori Hukum, (Ujung Pandang: Hasanuddin University Press, 1991), hlm. 28

15 Henry Campbell Black's, Black's Law Dictionary : Definition of the term and pharses of American and English Jurisfrudence, American and Modern, (ST Paul Mina: West Publisting Co, 1979), hlm. 1074.
} 
pikiran-pikiran dasar, yang terdapat di dalam dan di belakang system hokum masing-masing dirumuskan dalam aturan-aturan perundangundangan dan putusan-putusan hakim yang berkenaan dengan ketentuan-ketentuan dan keputusankeputusan individusl dapat dipandang sebagai penjabarannya. ${ }^{16}$ Satjipto Raharjo berpandangan bahwa asas hokum itu lebih abstrak dari aturan atau peraturan hokum; merupakan jantungnya huku, dimana di dalamnya terkandung nilai-nilai etis. ${ }^{17}$ Asas tersebut menurut Logemann sebagaimana dikutip Abu Daud Busroh dan Abubakar Busroh adalah sebagai bangunan hokum yang bersumber dari perasaan manusia, yang merupakan unsure idiil dari aturan. ${ }^{18}$ Karenanya ia bersifat dinamis berubah sesuai dengan kondisi-kondisi yang mempengaruhinya, sehingga tidak langgeng tergantung pada kondisi lingkungannya, yang ditentukan secara langsung atau disimpulkan baik secara langsung atau tidak langsung dari peraturan hokum yang berlaku pada saat itu, yang hakikinya telah mengandung unsure-unsur (kiem=bibit) dari asas hokum bersangkutan. ${ }^{19}$

Asas hokum yang berisikan nilai-nilai etis yang disebut juga sebagai kaidah penilaian dapat berfungsi baik di belakangataupun di dalam kaidah perilaku untuk kemudian mewujudkan kaidah

16 Bruggink, Refleksi Tentang Hukum (terjemahan : A. Sidharta), (Bandung : PT. Citra Aditya Bhakti, 1996), hlm. 119.

17 Satjipto Rahardjo, Ilmu Hukum, (Bandung: Alumni, 1982), hlm. 85.

${ }^{18}$ Abu Daud Busroh dan Abubakar Busroh, Asas-asas Hukum Tata Negara, (Jakarta: Ghalia Indonesia, 1985), hlm. 12.

19 ML. Tobing, Sekitar Pengantar Ilmu Hukum, (Jakarta: Erlangga, 1983), hlm. 22. hokum tertinggi dalam system hokum positif, karenanya asas hokum dalam hal ini berfungsi sebagai pondasi (landasan) bagi pembentukan system tersebut. ${ }^{20}$

$$
\text { Rusli Effendi dkk }
$$

menyebutkan bahwa asas hokum mempunyai fungsi antara lain :

1. Menjaga konsistensi tetap dapat dipertahankan dalam suatu system hokum, untuk menjaga agar konflik-konflik yang mungkin timbul dalam suatu system hokum dapat diatasi dan dicarikan jalan keluar pemecahannya.

2. Menertibkan aturan dan peraturan yang lebih konkret dan khusus serta kasuistis. ${ }^{21}$

Disamping itu, jika hokum mempunyai salah fungsi sebagai $a$ tool of social engeenering, maka asas hokum juga demikian. ${ }^{22}$ Akan tetapi, jika dipergunakan dalam upaya menemukan dan pembentukan hokum baru, maka asas hokum berfungsi sebagai batu uji kritis terhadap hokum positif. ${ }^{23}$

$$
\text { Pasal } 5 \text { Undang-Undang }
$$

Nomor 12 Tahun 2011 Tentang Pembentukan Peraturan PerundangUndangan (UU P3) ${ }^{24}$ ditentukan bahwa dalam membentuk Perda harus dilakukan berdasarkan pada asas Pembentukan Peraturan Perundang-undangan yang baik, yang meliputi: a). kejelasan tujuan; b). kelembagaan atau pejabat pembentuk yang tepat; c). kesesuaian antara jenis, hierarki, dan materi muatan; d). dapat dilaksanakan; e). kedayagunaan dan kehasilgunaan; f).

\footnotetext{
${ }^{20}$ Bruggink, Op.Cit., hlm. 132.

${ }^{21}$ Op.Cit., hlm. 97.

${ }^{22}$ Ibid., hlm. 100.

${ }^{23}$ Bruggink, Op.Cit., hlm. 133.

${ }^{24}$ LNRI Tahun 2011 No. 12, TLNRI No. 5234.
} 
kejelasan rumusan; dan g). keterbukaan.

Terkait dengan materi muatan Peraturan Perundang-undangan, Pasal 6 ayat (1) UU P3 menegaskan bahwa substansi Perda harus mencerminkan asas: a). pengayoman; b). kemanusiaan; c). kebangsaan; d). kekeluargaan; e). kenusantaraan; f). bhinneka tunggal ika; g). keadilan; h). kesamaan kedudukan dalam hukum dan pemerintahan; i). ketertiban dan kepastian hukum; dan/atau j). keseimbangan, keserasian, dan keselarasan.

Pembentukan Perda menurut Pasal 137 UU Pemda, ditentukan bahwa Perda dibentuk berdasarkan pada asas pembentukan peraturan perundang-undangan yang meliputi:

1. Kejelasan tujuan, yang berarti tujuan dari perda yang akan dibentuk tidak menyimpang dari tujuan dalam dasar filosofis, yuridis dan sosiologis.

2. Kelembagaan atau organ pembentuk yang tepat. Artinya, perda hanya dapat dibentuk atas kesepakatan bersama antara Kepala Daerah Kabupaten Tulang Bawang Barat dan DPRD baik berasal dari hak inisiatif lembaga legislatif atau oleh Kepala Daerah.

3. Kesesuaian antara jenis dan materi muatan. Artinya, materi muatan yang terkandung dalam perda yang akan dibentuk berkesesuaian dengan jenis perdanya. Pembentukan Perda tentang RPJMD merupakan Perda yang terkait dengan implementasi urusan wajib dan pilihan sebagaimana diatur dalam PP Nomor 38 Tahun 2007.

4. Dapat dilaksanakan. Artinya, perda yang akan dibentuk akan menjadi pedoman perilaku bagi semua pihak serta ketentuan pasal/norma dalam perda dapat diimplentasikan/operasional.

Pembentukan Perda tentang Rencana Pembangunan Jangka Menengah Daerah Kabupaten Tulang Bawang Barat akan menjadi dasar hokum bagi pemerintah, masyarakat dan pemangku kepentingan lainnya untuk melakukan hak dan kewajiban masing-masing.

5. Kedayagunaan dan kehasilgunaan. Artinya perda yang akan dibentuk dapat diterima baik secara filosofis, sosiologis dan yuridis. Pembentukan Perda Rencana Pembangunan Jangka Menengah Daerah Kabupaten Tulang Bawang Barat dilandasi dengan aspek filosofis, sosiologis dan yuridis, sehingga diharapkan keberlakuannya pun dapat tercermin secara filosofis, sosiologis dan yuridis.

6. Kejelasan rumusan. Artinya bahwa rumusan pasal dapat dipahami dan dilaksanakan dan tidak menimbulkan tafsir ganda (ambigu). Pembentukan Perda tentang Rencana Pembangunan Jangka Menengah Daerah Kabupaten Tulang Bawang Barat akan dirumuskan dengan menggunakan bahasa hukum yang tepat sehingga tidak multitafsir.

7. Keterbukaan. Artinya, peran serta masyarakat dapat diakomodasi baik dalam proses penyusunan, pelaksanaan maupun pengawasan. Pembentukan Perda tentang Rencana Pembangunan Jangka Menengah Daerah Kabupaten Tulang Bawang Barat akan melibatkan peran serta masyarakat baik dalam proses 
penyusunan, pelaksanaan maupun pengawasannya.

Asas-asas tersebut selanjutnya akan diserap dalam perumusan norma atau pasal yang menjadi materi muatan Perda yang akan disusun.

Selain asas pembentukan Perda, dalam menentukan materi muatan Pasal 138 ayat (1) UU Pemda menentukan bahwa materi muatan Perda mengandung asas : a) pengayoman; b) kemanusiaan; c) kebangsaan; d) kekeluargaan; e) kenusantaraan; f) bhineka tunggal ika; g) keadilan; h) kesamaan kedudukan dalam hukum dan pemerintahan; i) ketertiban dan kepastian hukum; dan/atau j) keseimbangan, keserasian, dan keselarasan.

Pasal 3 Permendagri Nomor 54 Tahun 2010 menyebutkan bahwa prinsip-prinsip perencanaan pembangunan daerah meliputi:

a. merupakan satu kesatuan dalam sistem perencanaan pembangunan nasional;

b. dilakukan pemerintah daerah bersama para pemangku kepentingan berdasarkan peran dan kewenangan masing-masing;

c. mengintegrasikan rencana tata ruang dengan rencana pembangunan daerah; dan

d. dilaksanakan berdasarkan kondisi dan potensi yang dimiliki masing-masing daerah, sesuai dinamika perkembangan daerah dan nasional.

Pasal 3 PP Nomor 8 Tahun 2008, serta Pasal 4 dan Pasal 5 Permendagri menyebutkan bahwa penyusunan perencanaan pembangunan daerah dirumuskan secara :

a) transparan, yaitu membuka diri terhadap hak masyarakat untuk memperoleh informasi yang benar, jujur, dan tidak diskriminatif tentang penyelenggaraan negara dengan tetap memperhatikan perlindungan atas hak asasi pribadi, golongan, dan rahasia negara

b) reponsif, yaitu dapat mengantisipasi berbagai potensi, masalah dan perubahan yang terjadi di daerah

c) efisien, yaitu pencapaian keluaran tertentu dengan masukan terendah atau masukan terendah dengan keluaran maksimal.

d) Efektif, merupakan kemampuan mencapai target dengan sumber daya yang dimiliki, dengan cara atau proses yang paling optimal.

e) Akuntabel, yaitu setiap kegiatan dan hasil akhir dari perencanaan pembangunan daerah harus dapat dipertanggungjawabkan kepada masyarakat atau rakyat sebagai pemegang kedaulatan tertinggi negara, sesuai dengan ketentuan peraturan perundang-undangan.

f) Partisipatif, merupakan hak masyarakat untuk terlibat dalam setiap proses tahapan perencanaan pembangunan daerah dan bersifat inklusif terhadap kelompok masyarakat rentan termarginalkan, melalui jalur khusus komunikasi untuk mengakomodasi aspirasi kelompok masyarakat yang tidak memiliki akses dalam pengambilan kebijakan.

g) Terukur, adalah penetapan target kinerja yang akan dicapai dan cara-cara untuk mencapainya.

h) Berkeadilan, adalah prinsip keseimbangan antarwilayah, sektor, pendapatan,gender dan usia. 
i) Berwawasan lingkungan, yaitu untuk mewujudkan kehidupan adil dan makmur tanpa harus menimbulkan kerusakan lingkungan yang berkelanjutan dalam mengoptimalkan manfaat sumber daya alam dan sumber daya manusia, dengan cara menserasikan aktivitas manusia dengan kemampuan sumber daya alam yang menopangnya; dan

j) Berkelanjutan yang berarti dapat dilaksanakan secara terus menerus sampai dengan batas akhir waktu yang telah ditentukan dan dapat menjadi bahan bagi penyusunan pada periode selanjutnya.

\subsection{Landasan Teoretis}

Tujuan nasional pembentukan pemerintahan Indonesia sebagai tujuan negara sebagaimana dirumuskan pendiri bangsa (the founding nation) dalam Pembukaan Undang-Undang Dasar Tahun 1945 (UUD Tahun 1945) adalah (1) melindungi segenap bangsa Indonesia dan seluruh tumpah darah Indonesia; (2) memajukan kesejahteraan umum; mencerdaskan kehidupan bangsa; dan (4) ikut melaksanakan ketertiban dunia yang berdasarkan kemerdekaan, perdamaian abadi dan keadilan social.

UUD Tahun 1945 adalah hokum dasar dalam peraturan perundang-undangan $^{25}$ yang berpuncak pada Pancasila sebagai sumber dari segala sumber hokum negara. $^{26}$ Sebagai hokum dasar, konstitusi menegaskan bahwa Pemerintahan daerah mengatur dan mengurus sendiri urusan

\footnotetext{
${ }^{25}$ Lihat Pasal 3 ayat (1) UU P3.

${ }^{26}$ Lihat Pasal 2 UU P3
}

pemerintahan menurut asas otonomi dan tugas pembantuan, ${ }^{27}$ untuk menjalankan otonomi (seluasluasnya $^{28}$ dan tugas pembantuan pemerintahan daerah berhak menetapkan peraturan daerah dan peraturan-peraturan lain. ${ }^{29}$

Sebagai daerah otonom yang mengurus dan menjalankan urusan yang terdesentralisasikan, daerah kabupaten dalam penyelenggaraan pemerintahan berpedoman kepada asas-asas pemerintahan yang baik, yaitu: a) asas kepastian hukum; b) asas tertib penyelenggara negara; c) asas kepentingan umum; d) asas keterbukaan; e) asas proporsionalitas; f) asas profesionalitas; g) asas akuntabilitas; h) asas efisiensi; dan i) asas efektivitas. ${ }^{30}$

Pasal 21 UU Pemda menegaskan bahwa sebagai daerah otonom yang menyelenggarakan urusan otonomi mempunyai hak untuk a). mengatur dan mengurus sendiri urusan pemerintahannya; b). memilih pimpinan daerah; c). mengelola aparatur daerah; d). mengelola kekayaan daerah; e). memungut pajak daerah dan retribusi daerah; f). mendapatkan bagi hasil dari pengelolaan sumber daya alam dan sumber daya lainnya yang berada di daerah; g). mendapatkan sumber-sumber pendapatan lain yang sah; dan h). mendapatkan hak lainnya yang diatur dalam peraturan perundang-undangan.

$$
\text { Sedangkan kewajiban }
$$
pemerintahan daerah berdasarkan Pasal 22 UU Pemda adalah meliputi : a. melindungi masyarakat, menjaga persatuan, kesatuan

\footnotetext{
${ }^{27}$ Lihat Pasal 18 ayat (2) UUD Tahun 1945.

${ }^{28}$ Lihat Pasal 18 ayat (5) UUD Tahun 1945.

${ }^{29}$ Lihat Pasal 18 ayat (6) UUD Tahun 1945.

${ }^{30}$ Lihat Pasal 20 ayat (1) UU Pemda.
} 
dan kerukunan nasional, serta keutuhan Negara Kesatuan Republik Indonesia;

b. meningkatkan kualitas kehidupan masyarakat;

c. mengembangkan kehidupan demokrasi;

d. mewujudkan keadilan dan pemerataan;

e. meningkatkan pelayanan dasar pendidikan;

f. menyediakan fasilitas pelayanan kesehatan;

g. menyediakan fasilitas sosial dan fasilitas umum yang layak;

h. mengembangkan sistem jaminan sosial;

i. menyusun perencanaan dan tata ruang daerah;

j. mengembangkan sumber daya produktif di daerah;

k. melestarikan lingkungan hidup;

1. mengelola administrasi kependudukan;

m. melestarikan nilai sosial budaya;

n. membentuk dan menerapkan peraturan perundang-undangan sesuai dengan kewenangannya; dan

o. kewajiban lain yang diatur dalam peraturan perundangundangan.

Yang keduanya, hak dan kewajiban tersebut diwujudkan dalam bentuk rencana kerja pemerintahan daerah dan dijabarkan dalam bentuk pendapatan, belanja, dan pembiayaan daerah yang dikelola dalam sistem pengelolaan keuangan daerah. ${ }^{31}$

Asas kepastian hukum dalam penyelenggaraan pemerintahan daerah, hak untuk mengatur dan mengurus sendiri urusan pemerintahannya, serta kewajiban

${ }^{31}$ Lihat Pasal 23 ayat (1) UU Pemda. untuk membentuk dan menerapkan peraturan perundang-undangan sesuai dengan kewenangannya adalah selaras dengan salah satu dari indikator pemerintahan yang baik dan bersih (good and clean government), yaitu prinsip akuntabilitas, yang dalam penjelasan Pasal 3 angka 7 Undang-Undang Nomor 28 Tahun 1999 tentang Penyelenggara Negara Yang Bersih Dan Bebas Dari Korupsi, Kolusi, Dan Nepotisme, ${ }^{32}$ diartikan sebagai asas yang menentukan bahwa setiap kegiatan dan hasil akhir dari kegiatan Penyelenggara Negara harus dapat dipertanggungjawab-kan kepada masyarakat atau rakyat sebagai pemegang kedaulatan tertinggi negara sesuai dengan ketentuan peraturan perundang-undangan yang berlaku.

Pertanggungjawaban tersebut menurut William C. Johnson sebagaimana dikutip Saldi Isra secara internal salah satunya dilakukan dengan adanya rule-making procedure dan secara eksternal dilakukan dengan adanya legislative rule-making. ${ }^{33}$

4 (empat) hal yang terkait dengan good and clean government adalah (1) good government; (2) clean government; (3) good governance; dan (3) clean governance, artinya paradigma yang hendak dikembangkan adalah pemerintahan yang baik dan bersih yang didukung oleh penyelenggara pemerintahan yang baik dan bersih. ${ }^{34}$ Secara lebih spesifik good

32 LNRI Tahun 1999 No. 75, TLNRI No. 3851 .

${ }^{33}$ Saldi Isra, Reformasi Hukum Tata Negara Pasca Amandemen UUD 1945, (Padang: Andalas University Press, 2006), hlm. 221222.

${ }^{34}$ Ibid., hlm. 218. 
covernance dapat diartikan sebagai suatu proyek sosial, hukum dan pemerintahan, yang melibatkan sektor negara, rakyat dan pasar, yang berisikan ketentuan yang mengatur hubungan antara unsur-unsur pemerintah, parlemen, pengadilan, dan rakyat dan lain-lain yang berkaitan dengan pengendalian pemerintahan. ${ }^{35}$ Penerapan Good Governance ke dalam pemerintahan dipengaruhi beberapa unsur penting yang saling kait mengait antara satu dan lainnya, yaitu :

1) Aturan hukum yang baik;

2) law Enforcement yang baik;

3) sistem peemrintahan yang efektif, efisien, jujur, transparan, accountable, dan berwawasan hak asasi manusia;

4) sistem pemerintahan yang dapat menciptakan masyarakat yang cerdas dan egaliter; dan

5) sistem pemerintahan yang kondusif terhadap pertumbuhan ekonomi dan pemerataan. ${ }^{36}$

Sesuai dengan kewenangan pemerintahan daerah yang terdapat dalam Pasal 18 ayat (6) UUD Tahun 1945, maka pembentukan perda apabila dikaitkan dengan prinsipprinsip good and clean governmant adalah dalam rangka menjamin kepastian hukum, dan apabila dikaitkan dengan fungsi peraturan perundang-undangan, maka peraturan daerah yang akan dibentuk secara internal berfungsi sebagai penciptaan hukum (recshepping), pembaharuan hukum, integritas hukum dan kepastian hukum, sedangkan secara eksternal, Perda berfungsi untuk melakukan perubahan, menjaga dan menjamin

35 Munir Fuady, Teori Negara Hukum Modern (Rechatstaat), (Bandung: Refika Aditama, 2009), hlm. 78.

${ }^{36}$ Ibid., hlm. 79. stabilitas masyarakat, dan berfungsi menjamin kemudahan bagi aparatur pemerintahan, masyarakat ataupun stake holder lainnya. $^{37}$

Terkait dengan implementasi good and clean government dan fungsi peraturan perundangundangan, maka substansi yang diatur dalam peraturan daerah sebagaimana diatur dalam Pasal 14 UU P3 adalah berisi materi muatan dalam rangka penyelenggaraan otonomi daerah dan tugas pembantuan serta menampung kondisi khusus daerah dan/atau penjabaran lebih lanjut Peraturan Perundang-undangan yang lebih tinggi. Dengan demikian, menurut Armen Yasir, materi yang diatur dalam perda adalah :

1) Dalam rangka penyelenggaraan otonomi daerah;

2) dalam rangka tugas pembantuan;

3) dalam kaitannya dengan kondisi khusus di daerah; dan

4) pengaturan lebih lanjut dari peraturan perundang-undangan yang lebih tinggi baik dilingkungan daerah yang bersangkutan maupun peraturan perundang-undangan yang berskala nasional. $^{38}$

Filosofi kewenangan otonom haruslah dipahami sebagai kewenangan untuk menyejahterakan rakyat dan bukan kewenangan dalam konteks kekuasaan semata. Berkenaan dengan hal tersebut, Perda dibuat atas dasar tujuan-tujuan tertentu yang ingin dicapai yang dilandaskan pada pedoman atau standar norma yang digariskan oleh pemerintah. Perda sebagai instrumen penyelenggaraan kekuasaan pemerintah daerah harus mempunyai

\footnotetext{
${ }^{37}$ Bandingkan dengan Amen Yasir, Hukum ..., Op.Cit., hlm. 30-33.

${ }^{38}$ Ibid., hlm. 85-86.
} 
karakter yang menghormati, melindungi dan memenuhi hak-hak masyarakat, khususnya masyarakat miskin dalam pelayanan publik yang diselenggarakannya. Karakter pengaturannya pun harus bersifat progresif, artinya pengaturan atau perda yang mengatur tentang pungutan kepada masyarakat tersebut tetap harus memahami kondisi sosial ekonomi masyarakat. Kualitas pelayanan pemerintah kepada masyarakatnya telah diberi patokanpatokan yang tertuang dalam Standar Pelayanan Minimal (SPM) yang telah ditetapkan pemerintah.

Substansi yang menjadi pengaturan dalam Perda Kabupaten berdasarkan Pasal 14 UU P3, Pasal 14 UU Pemda adalah terkait dengan pengimplementasian 16 (enam belas) rusan wajib yang menjadi kewenangan pemerintahan daerah untuk skala kabupaten, yang kemudian dijabarkan lebih luas menjadi 32 urusan dalam Peraturan Pemerintah Nomor 38 Tahun 2007 tentang Urusan Pembagian Urusan Pemerintahan Antara Pemerintah, Pemerintahan Daerah Provinsi, Dan Pemerintahan Daerah Kabupaten/ Kota yaitu mencakup urusan wajib : a) perencanaan dan pengendalian pembangunan; b) perencanaan, pemanfaatan, dan pengawasan tata ruang; c) penyelenggaraan ketertiban umum dan ketentraman masyarakat; d) penyediaan sarana dan prasarana umum; e) penanganan bidang kesehatan; f) penyelenggaraan pendidikan; g) penanggulangan masalah sosial; h) pelayanan bidang ketenagakerjaan; i) fasilitasi pengembangan koperasi, usaha kecil dan menengah; j) pengendalian lingkungan hidup; k) pelayanan pertanahan; 1) pelayanan kependudukan, dan catatan sipil; m) pelayanan administrasi umum pemerintahan; n) pelayanan administrasi penanaman modal; o) penyelenggaraan pelayanan dasar lainnya; dan p) urusan wajib lainnya yang diamanatkan oleh peraturan perundang-undangan.

Sedangkan urusan pilihan yang menjadi kewajiban daerah adalah terkait dengan urusan yang secara nyata ada dan berpotensi untuk meningkatkan kesejahteraan masyarakat sesuai dengan kondisi, kekhasan, dan potensi unggulan daerah yang bersangkutan.

Urusan wajib yang diselenggarakan pemerintahan daerah berdasarkan PP 38 tahun 2007 merupakan urusan yang terkait dengan pelayanan dasar yang mencakup 26 (dua puluh enam) urusan, yaitu : a) pendidikan; b) kesehatan; c) lingkungan hidup; d)pekerjaan umum; e) penataan ruang; f) perencanaan pembangunan; g) perumahan; h) kepemudaan dan olahraga; i) penanaman modal; j) koperasi dan usaha kecil dan menengah; k) kependudukan dan catatan sipil; 1) ketenagakerjaan; m) ketahanan pangan; n) pemberdayaan perempuan dan perlindungan anak; o) keluarga berencana dan keluarga sejahtera; p) perhubungan; q) komunikasi dan informatika; r) pertanahan; s) kesatuan bangsa dan politik dalam negeri; t) otonomi daerah, pemerintahan umum, administrasi keuangan daerah, perangkat daerah, kepegawaian, dan persandian; u) pemberdayaan masyarakat dan desa; p) sosial; w) kebudayaan; $\mathrm{x}$ ) statistik; y) kearsipan; dan z) perpustakaan.

Sedangkan yang terkait dengan urusan pilihan sebagaimana diamksud Pasal 7 ayat (4) PP No. 38 Tahun 2007 adalah mencakup 
urusan: a) kelautan dan perikanan; b) pertanian; c) kehutanan; d) energi dan sumber daya mineral; e) pariwisata; f) industri; g) perdagangan; dan $\mathrm{h}$ ) ketransmigrasian.

Dalam rangka mengimplementasikan kewenangan otonomi daerah yang luas tersebut dan pencapaian tujuannya agar lebih efektif dan efisien dibutuhkan koordinasi yang kuat antara pemerintah pusat, pemerintah provinsi dan pemerintah kabupaten/kota dalam merencanakan dan melaksanakan program-program pembangunan. Koordinasi antar sektor kegiatan juga sangat diperlukan dalam memecahkan permasalahan dan penyusunan prioritas pembangunan ke depan.

Perwujudan dari penyusunan prioritas pembangunan daerah diperintahkan Pasal 150 ayat (3) UU Pemda, Pasal 69 UU Nomor 33 Tahun 2004, UU Nomor 25 Tahun 2005, UU Nomor 17 Tahun 2007, PP Nomor 8 Tahun 2008, dan Permendagri Nomor 54 Tahun 2010 dalam bentuk dokumen berupa Rencana Pembangunan Jangka Panjang/Menengah Daerah yang kemudian diturunkan menjadi Rencana Kerja Tahun sebagai dasar penyusunan Anggaran Pendapatan dan Belanja Daerah (APBD).

RPJMD berdasarkan Pasal 50

Permendagri Nomor 54 Tahun 2010 memuat a) visi, misi, dan program kepala daerah; b) arah kebijakan keuangan daerah; c) strategi pembangunan daerah; d) kebijakan umum; e) program SKPD; f) program lintas SKPD; g) program kewilayahan; h) rencana kerja dalam kerangka regulasi yang bersifat indikatif; dan i) rencana kerja dalam kerangka pendanaan yang bersifat indikatif.

\begin{tabular}{lrrr}
\multicolumn{1}{c}{ Pasal } & $51 \quad$ Permendagri \\
menjelaskan & \multicolumn{2}{c}{ maksud } & dari \\
peristilahan & dalam & Pasal & 50
\end{tabular}

Permendagri, yaitu:

a. visi, misi, dan program kepala daerah merupakan keadaan masa depan yang diharapkan dan berbagai upaya yang akan dilakukan melalui programprogram pembangunan yang ditawarkan oleh Kepala Daerah terpilih.

b. arah kebijakan keuangan daerah merupakan pedoman dan gambaran dari pelaksanaan hak dan kewajiban daerah dalam rangka penyelenggaraan bidang urusan pemerintahan daerah yang dapat dinilai dengan uang termasuk didalamnya segala bentuk kekayaan yang berhubungan dengan hak dan kewajiban daerah tersebut.

c. strategi pembangunan daerah merupakan langkah-langkah berisikan program-program indikatif untuk mewujudkan visi dan misi dalam rangka pemanfaatan sumber daya yang dimiliki, untuk peningkatan kesejahteraan masyarakat yang nyata baik dalam aspek pendapatan, kesempatan kerja, lapangan berusaha, akses terhadap pengambilan kebijakan, berdaya saing, maupun peningkatan indeks pembangunan manusia.

d. kebijakan umum memberikan arah perumusan rencana program prioritas pembangunan yang disertai kerangka pengeluaran jangka menengah daerah dan menjadi pedoman bagi SKPD dalam menyusun program dan kegiatan Renstra SKPD.

e. program SKPD merupakan program yang dirumuskan berdasarkan tugas dan fungsi 
SKPD yang memuat indikator kinerja, lokasi program, tahun pelaksanaan, dan sumber daya yang diperlukan.

f. program lintas SKPD merupakan program yang melibatkan lebih dari satu SKPD untuk mencapai sasaran pembangunan yang ditetapkan termasuk indikator kinerja, lokasi program, tahun pelaksanaan, dan sumber daya yang diperlukan.

g. Program kewilayahan merupakan program pembangunan daerah untuk terciptanya keterpaduan, keserasian, keseimbangan laju pertumbuhan, dan keberlanjutan pembangunan antarwilayah/ antar-kawasan dalam kecamatan di wilayah kabupaten/kota atau antar kabupaten/kota di wilayah provinsi atau dengan provinsi lainnya berdasarkan rencana tata ruang wilayah.

h. rencana kerja dalam kerangka regulasi yang bersifat indikatif merupakan dasar hukum atau kebijakan yang dijadikan landasan perumusan dan pelaksanaan program pembangunan daerah.

i. rencana kerja dalam kerangka pendanaan yang bersifat indikatif merupakan tahapan dan jadwal pelaksanaan program, dengan dilengkapi jumlah pagu indikatif berdasarkan prakiraan maju dan sumber pendanaannya, untuk mencapai target dan sasaran yang ditetapkan.

Adapun tahapan penyusunan RPJMD berdasarkan Permendagri adalah sebagai berikut :

1. persiapan penyusunan RPJMD, yang meliputi :
a. penyusunan rancangan
keputusan kepala daerah tentang pembentukan tim penyusun RPJMD;

b. orientasi mengenai RPJMD;

c. penyusunan agenda kerja tim penyusun RPJMD; dan

d. penyiapan data dan informasi perencanaan pembangunan daerah.

2. penyusunan rancangan awal RPJMD disusun :

a. memuat visi, misi dan program bupati dan wakil bupati terpilih atau walikota dan wakil walikota terpilih;

b. berpedoman pada RPJPD dan RTRW kabupaten/kota; dan

c. memperhatikan RPJMN, RPJMD provinsi, RPJMD dan RTRW kabupaten/kota lainnya.

3. penyusunan rancangan RPJMD, rancangan awal RPJMD disampaikan Bappeda kepada Kepala SKPD untuk kemudian dilakukan verifikasi untuk melakukan harmonisasi awal :

a. memecahkan isu-isu strategis sesuai dengan tugas dan fungsi masing-masing SKPD;

b. menyelaraskan dengan visi, misi, tujuan dan sasaran;

c. menyelaraskan dengan strategi dan arah kebijakan;

d. mempedomani kebijakan umum dan program pembangunan daerah; dan

e. mempedomani indikasi rencana program prioritas yang disertai kebutuhan pendanan.

4. pelaksanaan musrenbang RPJMD dilaksanakan dan dikoordinasikan Bappedda provisi dan kabupaten yang bertujuan untuk penajaman, penyelarasan, klarifikasi dan kesepakatan terhadap rancangan RPJMD yang mencakup :

a. sasaran pembangunan jangka menengah daerah; 
b. strategi dan sinkronisasi arah kebijakan pembangunan jangka menengah daerah dengan pendekatan atasbawah dan bawah-atas, sesuai dengan kewenangan penyelenggaraan pemerintahan daerah;

c. kebijakan umum dan program pembangunan jangka menengah daerah dengan visi, misi dan program kepala daerah dan wakil kepala daerah;

d. indikasi rencana program prioritas pembangunan jangka menengah daerah yang disesuaikan dengan kemampuan pendanaan;

e. capaian indikator kinerja daerah pada kondisi saat ini dan pada akhir periode RPJMD;

f. komitmen bersama antara pemangku kepentingan untuk mempedomani RPJMD dalam melaksanakan pembangunan daerah; dan

g. sinergi dengan RPJMN, dan RPJMD daerah lainnya.

5. perumusan rancangan akhir RPJMD merupakan sepakatan dan ditandatangani oleh yang mewakili setiap unsur pemangku kepentingan yang menghadiri musrenbang untuk kemudian dibahasa kepala SKPD dengan tujuan memastikan program pembangunan jangka menengah sesuai dengan tugas dan fungsi masing-masing SKPD telah tertampung dalam rancangan akhir RPJMD. Untuk selanjutnya dikonsultasikan kepada Gubernur.

6. penetapan Peraturan Daerah tentang RPJMD kabupaten dilakukan dengan pembahasan bersama Raperda RPJMD yang diajukan Bupati paling lambat 5 (lima) setelah dilantik untuk kemudian menjadi perda.

\section{Penutup}

3.1. Simpulan

a. Asas-asas yang terdapat dalam Naskah Akademik tentang RPJMD Kabupaten Tulang Bawang Barat Tahun 2011-2016 adalah asas hukum yang diatur dalam UU Pemda 2004 dan UU No. 12 Tahun 2011.

b. Landasan teoretis yang dapat dipergunakan dalam Naskah Akademik tersebut antara lain terkait dengan urusan yang menjadi wewenang pemerintahan dalam skala kabupaten berdasarkan peraturan perundangundangan terkait.

\section{B. Saran}

Mengingat bahwa asas-asas hukum tidaklah bersifat aplikatif, maka asas tersebut tidaklah merupakan kaidah normatif yang akan ditempatkan dalam perda.

\section{Daftar Pustaka}

Abu Daud Busroh dan ABubakar Busroh, 1985, Asas-asas Hukum Tata Negara, (Jakarta: Ghalia Indonesia)

Armen Yasir, 2007, Hukum Perundang-undangan, (Bandar Lampung: Universitas Lampung)

Bruggink, 1996, Refleksi Tentang Hukum (terjemahan: A. Sidharta), (Bandung : PT. Citra Aditya Bhakti) 
H.L.A. Hart, 2009, Konsep Hukum (The Concept Of Law), (Bandung: Nusamedia)

Henry Campbell Black's, 1979, Black's Law Dictionary : Definition of the term and pharses of American and English Jurisfrudence, American and Modern, (ST Paul Mina: West Publisting Co)

Imam Syaukani, dan A. Ahsin Thohari, 2008, Dasar-Dasar Politik Hukum, (Jakarta: Raja Grafindo Persada)

Jimly Asshiddiqie, 2006, Perihal Undang-undang, (Jakarta: Konstitusi Pres)

John, Gilissen dan Fritz Gorle. 2007, Historische Inleiding Tot Het Recht, (Terjemahan : Freddy Tengker), Sejarah Hukum, (Bandung :PT Refika Aditama)

ML. Tobing, 1983, Sekitar Pengantar Ilmu Hukum, (Jakarta: Erlangga)

Munir Fuady, 2009, Teori Negara Hukum Modern (Rechatstaat), (Bandung: Refika Aditama)

Peter Salim dan Yenny Salim, 1991, Kamus Bahasa Indonesia Kontemporer, (Jakarta: Modern English Press)

Rulis Effendi, dkk, 1991, Teori Hukum, (Ujung Pandang: Hasanuddin University Press)

Saldi Isra, 2006, Reformasi Hukum Tata Negara Pasca Amandemen UUD 1945, (Padang: Andalas University Press)

Satjipto Rahardjo, 1982, Ilmu Hukum, (Bandung: Alumni)

Tim Penyusun, 2002, Kamus Besar Bahasa Indonesia, (Jakarta: Departemen Pendidikan dan Kebudayaan RI)

Undang-Undang Dasar Tahun 1945.
Indonesia, Undang-Undang Nomor 32 Tahun 2004 tentang Pemerintahan Daerah (LNRI Tahun 2004 Nomor 125, TLNRI Nomor 4437) sebagaimana telah diubah beberapa kali, terakhir dengan Undang-Undang Nomor 12 Tahun 2008 tentang Perubahan Kedua Atas Undang-Undang Nomor 32 Tahun 2004 Tentang Pemerintahan Daerah (LNRI Tahun 2008 Nomor 59, TLNRI Nomor 4844); ,Undang-undang Nomor 17 Tahun 2003 tentang Keuangan Negara (LNRI Tahun 2003 Nomor 47, TLNRI Nomor 4286. ,Undang-Undang Nomor 1 Tahun 2004 tentang Perbendaharaan Negara (LNRI Tahun 2004 Nomor 5, TLNRI Nomor 4355). ,Undang-Undang Nomor 15 Tahun 2004 tentang Pemeriksaan Pengelolaan dan Tanggungjawab Keuangan Negara (LNRI Tahun 2004 Nomor 66, TLNRI Nomor 4400).

, Undang-Undang Nomor 25 Tahun 2004 tentang Sistem Perencanaan Pembangunan Nasional (LNRI Tahun 2004 Nomor 104, TLNRI Nomor 4421); ,Undang-Undang Nomor 33 Tahun 2004 tentang Perimbangan Keuangan Antara Pemerntah Pusat dan Pemerinta Daerah (LNRI Tahun 2004 Nomor 126, TLNRI Nomor 4438).

,Undang-Undang Nomor 17 Tahun 2007 tentang Rencana Gpembangunan Janaka Panjang Nasional 2005-2025 
(LNRI Tahun 2007 Nomor 33, TLNRI Nomor 4700); ,Undang-Undang Nomor

50 Tahun 2008 tentang

Pembentukan Kabupaten

Tulang Bawang Barat di Lampung (LNRI Tahun 2008

Nomor 187, TLNRI Nomor 4934)

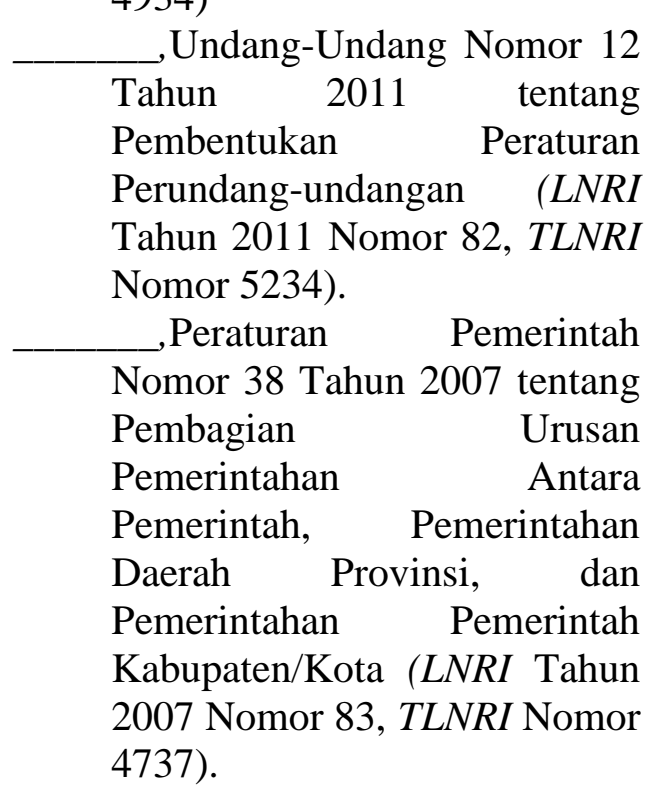

,Peraturan Pemerintah Nomor 8 Tahun 2008 tentang Tahapan, Tata cara Penyusunan, Pengendalian, dan Evaluasi Pelaksanaan Rencana Pembangunan Daerah (LNRI Tahun 2008 Nomor 21, TLNRI Nomor 4817); ,Peraturan Presiden

Nomor 5 Tahun 2010 tentang Rencana Pembangunan Jangka Menengah Nasional 20102014;

,Peraturan Menteri Dalam Negeri Nomor 54 Tahun 2010 tentang Pelaksanaan Peraturan Pemerintah Nomor 8 Tahun 2008 tentang Tahapan, Tata cara Penyusunan, Pengendalian, dan Evaluasi pelaksanaan Rencana Pembangunan Daerah.
Peraturan Daerah Provinsi Lampung Nomor 6 Tahun 2007 tentang Rencana Pembangunan Jangka anjang Daerah (RPJPD) Provinsi Lampung Tahun 2005-2025

$\begin{array}{lrr}\text { Peraturan Gubernur } & \text { Provinsi } \\ \text { Lampung Nomor } & \text { 41 } & \text { Tahun } \\ 2009 & \text { tentang } & \text { Rencana } \\ \text { Pembangunan } & \text { Jangka } \\ \text { Menengah } & \text { Daerah } & \text { (RPJMD) } \\ \text { Provinsi } & \text { Lampung } & \text { Tahun } \\ 2010-2014 & & \end{array}$

Peraturan Daerah Kabupaten Tulang Bawang Barat Nomor 2 tahun 2012 tentang Rencana Tata Ruang Wilayah Kabupaten Tulang Bawang Barat Tahun 2011-20131 (Lembaran Daerah Tulang Bawang Barat Nomor 17). 